\title{
Performance of Grid-Connected Photovoltaic System in Two Sites in Kuwait
}

\author{
Ali Hajiah,, ${ }^{1}$ Tamer Khatib, ${ }^{2}$ K. Sopian, ${ }^{3}$ and M. Sebzali ${ }^{1}$ \\ ${ }^{1}$ Kuwait Institute for Scientific Research (KISR), Safat 13109, Kuwait \\ ${ }^{2}$ Department of Electrical, Electronic \& System Engineering, Faculty of Engineering \& Built Environment, \\ Universiti Kebangsaan Malaysia, Bangi 43600, Malaysia \\ ${ }^{3}$ Solar Energy Research Institute, Universiti Kebangsaan Malaysia, Bangi 43600, Malaysia
}

Correspondence should be addressed to Tamer Khatib, tamer_khat@hotmail.com

Received 13 September 2012; Revised 14 October 2012; Accepted 15 October 2012

Academic Editor: Tapas Mallick

Copyright (C) 2012 Ali Hajiah et al. This is an open access article distributed under the Creative Commons Attribution License, which permits unrestricted use, distribution, and reproduction in any medium, provided the original work is properly cited.

This paper presents an assessment of the electricity generated by photovoltaic (PV) grid-connected systems in Kuwait. Three years of meteorological data are provided for two main sites in Kuwait, namely, Al-Wafra and Mutla. These data and a PV grid-connected system mathematical model are used to assist a $100 \mathrm{kWp}$ grid-connected PV system proposed for both sites. The proposed systems show high energy productivity whereas the annual capacity factors for Mutla and Al-Wafra are 22.25\% and 21.6\%, respectively. Meanwhile the annual yield factors for Mutla and Al-Wafra are $1861 \mathrm{kWh} / \mathrm{kWp} /$ year and $1922.7 \mathrm{kWh} / \mathrm{kWp} /$ year, respectively. On the other hand the cost of the energy generated by both systems is about $0.1 \mathrm{USD} / \mathrm{kWh}$ which is very close to the price of the energy sold by the Ministry of Electricity and Water (MEW). Furthermore the invested money is recovered during the assumed life cycle time whereas the payback period for both sites is about 15 years. This work contains worthwhile technical information for those who are interested in PV technology investment in Kuwait.

\section{Introduction}

Based on the fact that PV systems are clean, environment friendly, and secure energy sources, PV system installation has played an important role worldwide. However, the drawback of PV systems is the high capital cost as compared to conventional energy sources. Therefore, many research works are carried out currently focusing on optimization of PV systems [1]. Grid-connected PV systems can be divided into two parts: building integrated PV systems (BiPV) and distribution generation PV (DGPV) systems. BiPV systems usually supply a specific load and inject the excess energy to the grid. On the other hand the DGPV systems inject the whole produced energy to the grid without feeding any local load. The grid-connected systems can consist of a PV array only as an energy source, or anther energy source can be in cooperation with the PV array such as wind turbine, diesel system, or a storage unit [2].

PV system size and performance strongly depend on metrological variables such as solar energy, wind speed, and ambient temperature and, therefore, to optimize a PV system, extensive studies related to the metrological variables have to be done [3]. The importance of the meteorological data in sizing PV systems lies in the fact that the PV modules output energy strongly depends on the available solar energy and the ambient temperature, while the wind turbines (in case of hybrid PV/Wind systems) output power is a function of the available wind speed.

The performance of a PV module strongly depends on the sun light conditions. Standard sunlight conditions on a clear day are assumed to be 1000 watt of solar energy per square meter and it is sometimes called "one sun" or a "peak sun." Less than one sun will reduce the current output of a PV module by a proportional amount [1]. Furthermore, cell temperature, $T_{c}$, is an important factor in determining the performance of PV cells. The increase in cell temperature decreases PV module's voltage linearly, while increasing cell temperature increases PV module's current. The effect of cell temperature on PV modules performance depends on PV cells manufacturing. However, increasing cell temperature by 
TABLE 1: Monthly mean of daily solar radiation and ambient temperature for Al-Wafra and Mutla sites.

\begin{tabular}{|c|c|c|c|c|}
\hline \multirow{2}{*}{ Month } & \multicolumn{2}{|c|}{ Mutla station } & \multicolumn{2}{|c|}{ Al-Wafra station } \\
\hline & Solar radiation & Temperature & Solar radiation & Temperature \\
\hline JAN & $319\left(\mathrm{~W} / \mathrm{m}^{2}\right)$ & $14.3\left({ }^{\circ} \mathrm{C}\right)$ & $326\left(\mathrm{~W} / \mathrm{m}^{2}\right)$ & $14.7\left({ }^{\circ} \mathrm{C}\right)$ \\
\hline FEB & $325\left(\mathrm{~W} / \mathrm{m}^{2}\right)$ & $19.4\left({ }^{\circ} \mathrm{C}\right)$ & $351\left(\mathrm{~W} / \mathrm{m}^{2}\right)$ & $19.9\left({ }^{\circ} \mathrm{C}\right)$ \\
\hline MAR & $446\left(\mathrm{~W} / \mathrm{m}^{2}\right)$ & $23.1\left({ }^{\circ} \mathrm{C}\right)$ & $494\left(\mathrm{~W} / \mathrm{m}^{2}\right)$ & $23.4\left({ }^{\circ} \mathrm{C}\right)$ \\
\hline APR & $484\left(\mathrm{~W} / \mathrm{m}^{2}\right)$ & $28.6\left({ }^{\circ} \mathrm{C}\right)$ & $473\left(\mathrm{~W} / \mathrm{m}^{2}\right)$ & $24.9\left({ }^{\circ} \mathrm{C}\right)$ \\
\hline MAY & $512\left(\mathrm{~W} / \mathrm{m}^{2}\right)$ & $37.8\left({ }^{\circ} \mathrm{C}\right)$ & $568\left(\mathrm{~W} / \mathrm{m}^{2}\right)$ & $37.2\left({ }^{\circ} \mathrm{C}\right)$ \\
\hline JUN & $546\left(\mathrm{~W} / \mathrm{m}^{2}\right)$ & $42.2\left({ }^{\circ} \mathrm{C}\right)$ & $629\left(\mathrm{~W} / \mathrm{m}^{2}\right)$ & $42.9\left({ }^{\circ} \mathrm{C}\right)$ \\
\hline JUL & $599\left(\mathrm{~W} / \mathrm{m}^{2}\right)$ & $42.5\left({ }^{\circ} \mathrm{C}\right)$ & $624\left(\mathrm{~W} / \mathrm{m}^{2}\right)$ & $44.3\left({ }^{\circ} \mathrm{C}\right)$ \\
\hline AUG & $604\left(\mathrm{~W} / \mathrm{m}^{2}\right)$ & $42\left({ }^{\circ} \mathrm{C}\right)$ & $578\left(\mathrm{~W} / \mathrm{m}^{2}\right)$ & $43.6\left({ }^{\circ} \mathrm{C}\right)$ \\
\hline SEP & $565\left(\mathrm{~W} / \mathrm{m}^{2}\right)$ & $36.9\left({ }^{\circ} \mathrm{C}\right)$ & $564\left(\mathrm{~W} / \mathrm{m}^{2}\right)$ & $40.8\left({ }^{\circ} \mathrm{C}\right)$ \\
\hline OCT & $514\left(\mathrm{~W} / \mathrm{m}^{2}\right)$ & $31.6\left({ }^{\circ} \mathrm{C}\right)$ & $459\left(\mathrm{~W} / \mathrm{m}^{2}\right)$ & $33.7\left({ }^{\circ} \mathrm{C}\right)$ \\
\hline NOV & $423\left(\mathrm{~W} / \mathrm{m}^{2}\right)$ & $20.2\left({ }^{\circ} \mathrm{C}\right)$ & $387\left(\mathrm{~W} / \mathrm{m}^{2}\right)$ & $26\left({ }^{\circ} \mathrm{C}\right)$ \\
\hline DEC & $378\left(\mathrm{~W} / \mathrm{m}^{2}\right)$ & $18.9\left({ }^{\circ} \mathrm{C}\right)$ & $319\left(\mathrm{~W} / \mathrm{m}^{2}\right)$ & $18.3\left({ }^{\circ} \mathrm{C}\right)$ \\
\hline AV. & $476\left(\mathrm{~W} / \mathrm{m}^{2}\right)$ & $29.79\left({ }^{\circ} \mathrm{C}\right)$ & $481\left(\mathrm{~W} / \mathrm{m}^{2}\right)$ & $30.8\left({ }^{\circ} \mathrm{C}\right)$ \\
\hline
\end{tabular}

1 Celsius, C, degree decreases PV modules voltage by 0.085 $0.123 \mathrm{~V}$. On the other hand, increasing cell temperature by $1 \mathrm{C}$ increases PV modules current by $0.0026-0.0032 \mathrm{~A}[1]$. Based on this, increasing cell temperature by $1 \mathrm{C}$ degree decreases PV module's power by $0.5-0.6 \%$. In general, most of PV modules are being tested at $25 \mathrm{C}$ degrees; thus, a different output power is expected when PV modules are working under different climate conditions. As for wind speed, the wind turbine output energy depends on the amount of wind power which hits the blades of a wind turbine. Therefore, to predict the energy produced by a wind turbine located in a specific location, a comprehensive study of the wind speed characteristic for this location must be done.

In general, the most common optimization methodology that is followed by the researchers starts by defining a specific area, and then a time series data for solar energy, ambient temperature, and wind (in case of hybrid PV/wind system) must be obtained. After that, the calculation of optimum tilt angle is conducted by modeling the solar energy on a tilt surface. Then based on the nature of the PV system (standalone, grid, or hybrid) the calculation of system energy sources (PV array battery, wind turbine, and diesel generator) optimum capacity is done. Finally, the size of the inverter in the PV system is calculated optimally.

However, according to a World Bank report published in 2010, the electricity production (MWh) in Kuwait was reported at $57082 \mathrm{GWh}$ in 2010 [4]. This energy is totally generated by fossil fuel $(64.4 \%$ oil sources and $35.7 \%$ natural gas), while the alternative energy sources including solar, wind, hydro-, and nuclear ones are not used at all [5]. Based on this, the Kuwaiti government has set recently the most ambitious target for using renewable energy in the Gulf region. The new Kuwaiti government renewable energy policy aims to generate $10 \%$ of its electricity from sustainable sources by 2020. The Kuwaiti government is trying to free up oil for export and expand its generation capacity to support increased tourism, manufacturing, and home building in a \$112-billion development program. However, renewable energy is a new subject for Kuwait, and that is why there is a lack of information regarding the suitability of renewable energy sources for Kuwait's weather [6].

Kuwait is a desert country with high numbers of sun shining hour per day and, therefore, the use of PV grid-connected systems for electricity generation is promising at this country. Based on this, the main objective of this paper is to assist the electricity generated by PV grid-connected systems located at two main sites in Kuwait, namely, Al-Wafra and Mutla. This assessment-which is done using technical and economical criteria-provides worthwhile information for those who are interested in PV system installation at Kuwait. This work is done based on real meteorological data for the period 2009-2011. These data are provided by the Kuwait National Meteorological Network (KNMN) at KISR.

\section{Solar Energy Potential in the Selected Sites}

In this paper weather profiles for two sites located in Kuwait, namely, Mutla and Al-Wafra are analyzed. Mutla is located at latitude N $29^{\circ} 22^{\prime} 54^{\prime \prime}$ and longitude $47^{\circ} 37^{\prime} 50^{\prime \prime}$. Meanwhile Al-Wafra is located at latitude: $28^{\circ} 37^{\prime} 01^{\prime \prime}$ and longitude $48^{\circ}$ $00^{\prime} 29^{\prime \prime}$. The analyzed weather profiles contain solar radiation and ambient temperature data for three years (20092011). Figure 1 shows the mean hourly solar radiation for both sites. From the figure, both sites have almost the same solar radiation profile whereas it reaches the maximum value $\left(1000 \mathrm{~W} / \mathrm{m}^{2}\right)$ in the summer time (June-August) while the minimum mean value is usually happening in the winter time (November-February). However both sites are desert sites with high clearness index along the year and, therefore, most of global solar radiation recorded consisted of direct solar radiation. On the other hand, Figure 2 shows the ambient temperature profile for both sites. The ambient temperature for both sites is in the range of $10-50^{\circ} \mathrm{C}$ with peak value in the summer time and minimum value in the winter time.

Table 1 shows the monthly mean daily solar radiation and ambient temperature for Al-Wafra and Mutla sites. The average ambient temperature for both sites is $28.78^{\circ} \mathrm{C}$, and 


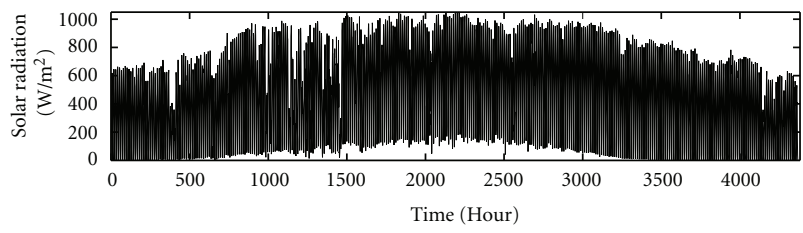

- Al-Wafra station

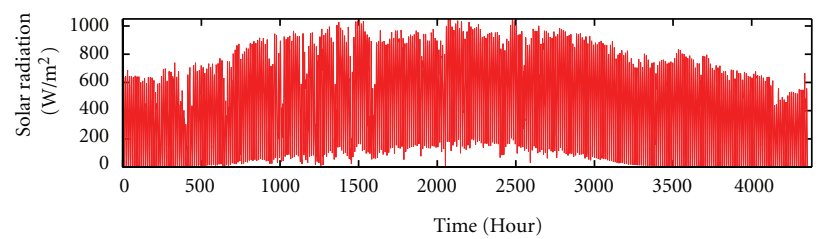

Mutla station

(a)

(b)

FIgURE 1: Hourly solar radiation profile for Al-Wafra and Mutla sites.

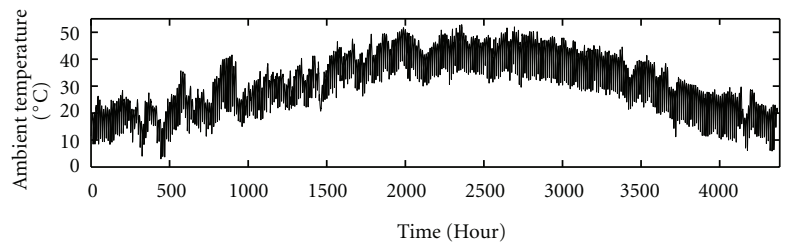

_ Al-Wafra station

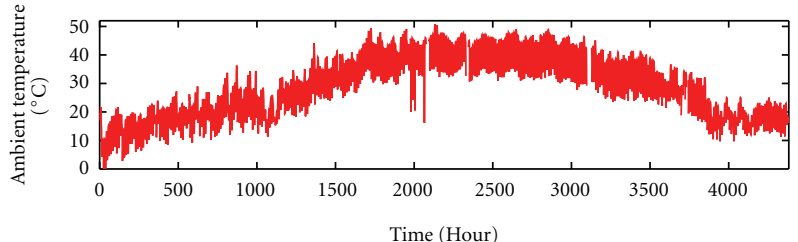

Mutla station

(a)

(b)

Figure 2: Ambient temperature profiles for Al-Wafra and Mutla sites.

$30.8^{\circ} \mathrm{C}$, respectively. On the other hand the average solar radiation for Mutla site is $476 \mathrm{~W} / \mathrm{m}^{2}$. This means that the annual mean daily solar energy received at this site is $5.712 \mathrm{kWh} / \mathrm{m}^{2}$ (the peak sunshine hours is 5.7 ). As for AlWafra, the annual mean daily solar radiation is $481 \mathrm{~W} / \mathrm{m}^{2}$ which leads to that the annual mean daily solar energy is $5.772 \mathrm{kWh} / \mathrm{m}^{2}$ (the peak sunshine hours is 5.8 ). Based on this, both sites have high solar energy potential and it is expected that PV systems productivity will be high as compared to other renewable energy alternatives.

\section{PV Grid-Connected System Model}

Figure 3 shows the typical component of a grid-connected system consisting of a PV array, DC-AC inverter and a grid interconnection point. Based on this, the mathematical model of the PV grid-connected system must contain the mathematical model of the PV array as well as the inverter [7].

3.1. PV Array Mathematical Model. The output power of a PV array depends on the available solar radiation $(G)$ and the ambient temperature $(T)$. The output power of a PV array increases linearly as the solar radiation increases and decreases as the ambient temperature increases. Thus, the instantaneous output power of a PV array [1] can be given by

$$
P_{\mathrm{PV}}(t)=P_{\text {Peak }}\left(\frac{G(t)}{G_{\text {standard }}}\right)-\alpha_{T}\left[T_{c}(t)-T_{\text {standard }}\right],
$$

where $G_{\text {standard }}$ and $T_{\text {standard }}$ are the standard test conditions for solar radiation and cell temperature, respectively, and $\alpha_{T}$

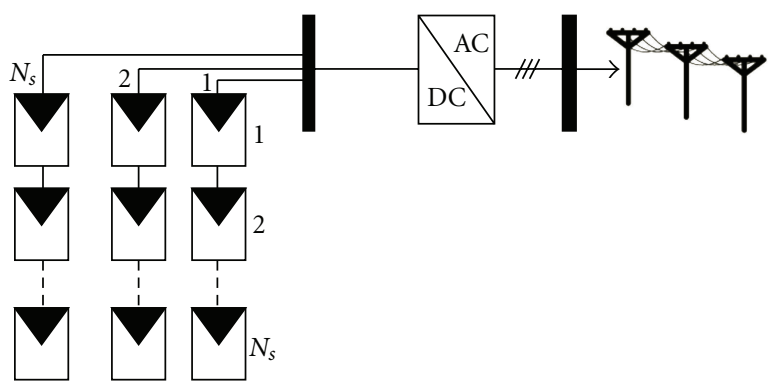

Figure 3: PV grid-connected system components.

is the temperature coefficient of the PV module power which can be obtained from the datasheet [1]. $P_{\text {peak }}$ is the rated power of the PV array while $T_{c}$ is the cell temperature and it is given by

$$
T_{c}(t)-T_{\text {ambient }}=\frac{T_{\text {standard }}}{800} G(t)
$$

To extract maximum power from a PV array which is under varying weather and load conditions, maximum power point trackers (MPPTs) are used. Such a device ensures maximum power operation of PV array and in this case the PV array is assumed to be operating at maximum power output, $P_{\text {peak }}$. However, based on (1), the calculation of PV array output power requires solar radiation and ambient temperature records, and, therefore, hourly solar radiation and ambient temperature records for the adopted sites have been obtained. 
3.2. Inverter Mathematical Model. The efficiency of an inverter [1] is calculated by

$$
\eta(t)=\frac{P_{\text {in }}(t)-P_{\text {Loss }}(t)}{P_{\text {in }}(t)},
$$

where $P_{\text {in }}(t)$ and $P_{\text {Loss }}(t)$ are the instantaneous input power and power loss during the conversion.

Ignoring the wire efficiency, the input power to the PV system is the output power of the PV module. The $P_{\text {Loss }}$ is not constant but depends on many conditions which make it difficult to be calculated. Thus, an alternative model for inverter efficiency needs to be developed in order to estimate the inverter's output power.

Figure 4 shows an efficiency curve for a commercial inverter obtained from the datasheet. The curve describes the inverter's efficiency (in percent) in terms of input power and inverter rated power.

The efficiency curve can be described by a power function as follows:

$$
\begin{gathered}
\eta=c_{1}\left(\frac{P_{\mathrm{PV}_{\text {input }}}}{P_{\mathrm{INV}_{\text {Rated }}}}\right)^{c_{2}}+c_{3}, \quad \frac{P_{\mathrm{PV}_{\text {input }}}}{P_{\mathrm{INV}_{\text {Rated }}}}>0, \\
\eta=0, \quad \frac{P_{\mathrm{PV}_{\text {input }}}}{P_{\mathrm{INV}_{\text {Rated }}}}=0,
\end{gathered}
$$

where $P_{\mathrm{PV}}$ and $P_{\mathrm{INV}}$ are $\mathrm{PV}$ module output power and inverter's rated power, respectively, while $c_{1}-c_{3}$ are the model coefficients.

A MATLAB fitting tool can be used for calculating the developed inverter model coefficients, $c_{1}-c_{3}$. Therefore, samples of the inverter's efficiency curve shown in Figure 4 must be taken for the purpose of curve fitting using the MATLAB fitting tool. Intensive number of samples must be taken for a specific part of the curve as in zone $\mathrm{B}$, less intensive number of samples are taken from the zone A, while few samples are taken from the zone $\mathrm{C}$ as described in Figure 4.

\section{PV Grid-Connected Evaluation Criteria}

To judge the feasibility of a grid-connected PV system, technical and economical evaluation criteria can be applied. In this paper technical criteria, namely, capacity factor and yield factor are applied. On the other hand, the cost of energy produced by the system $(\mathrm{CoE})$ and the payback period are used as economical evaluation criteria.

The yield factor (YF) is defined as the annual, monthly, or daily net AC energy output of the system divided by the peak power of the installed PV array at standard test conditions (STC) and it is given by [7]

$$
\mathrm{YF}=\frac{E_{\mathrm{PV}}(\mathrm{kWh} / \text { year })}{\mathrm{PV}_{\mathrm{WP}}(\mathrm{kWp})} .
$$

This factor assists the productivity of a PV array under certain weather conditions. On the other hand, the capacity factor (CF) is defined as the ratio of the actual annual energy output to the amount of energy the PV array would generate

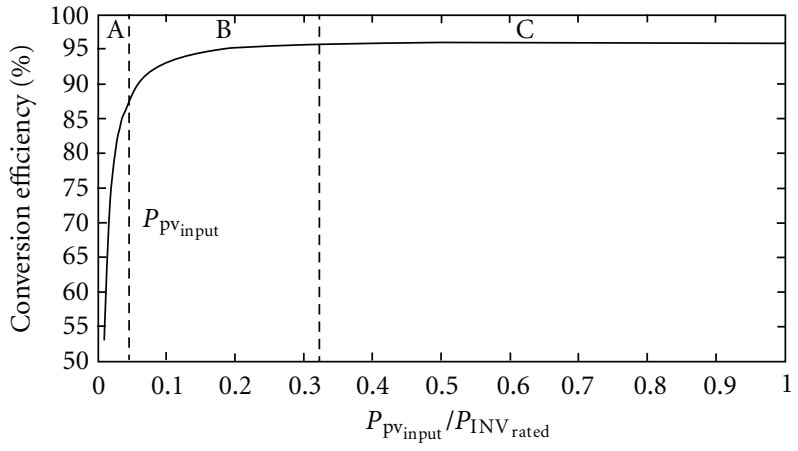

FIgUre 4: Typical efficiency curve for an inverter.

if it operated at full rated power (Pr) for $24 \mathrm{~h}$ per day for a year [7]:

$$
\mathrm{CF}=\frac{Y_{F}}{8760}=\frac{E_{\mathrm{PV}_{\text {annual }}}}{P_{R} * 8760} .
$$

This factor evaluates the usage of the PV array. However, the economical evaluation criteria, the life cycle cost, unit cost, and payback period criteria are used, and the life cycle cost is given by

$$
\begin{aligned}
\mathrm{LCC}= & C_{\text {capital }}+\sum_{1}^{n} C_{\mathrm{O} \& \mathrm{M}} R_{\mathrm{PW}} \\
& +\sum_{1}^{n} C_{\text {replacement }} R_{\mathrm{PW}}-C_{\text {salvage }} R_{\mathrm{PW}} .
\end{aligned}
$$

The capital cost $\left(C_{\text {capital }}\right)$ of a project includes the initial capital expense for equipment, the system design, engineering, and installation. This cost is always considered as a single payment occurring in the initial year of the project, regardless of how the project is financed. Maintenance $\left(C_{\mathrm{O} \& \mathrm{M}}\right)$ is the sum of all yearly scheduled operation and maintenance $(\mathrm{O} \& \mathrm{M})$ costs. However, equipment replacement costs are not included. O\&M costs include such items as an operator's salary, inspections, insurance, property tax, and all scheduled maintenance. Replacement cost $\left(C_{\text {replacement }}\right)$ is the sum of all repair and equipment replacement cost anticipated over the life of the system. The replacement of a battery is a good example of such a cost that may occur once or twice during the life of a PV system. Normally, these costs occur in specific years and the entire cost is included in those years. The salvage value ( $\left.C_{\text {salvage }}\right)$ of a system is its net worth in the final year of the life cycle period. It is common practice to assign a salvage value of 20 percent of original cost for mechanical equipment that can be moved. This rate can be modified depending on other factors such as obsolescence and condition of equipment. Future costs must be discounted because of the time value of money. One dollar received today is worth more than the promise of $\$ 1$ next year, because the $\$ 1$ today can be invested and earn interest. Future sums of money must also be discounted because of the inherent risk of future events not occurring as planned. Several factors should be considered when the period for 
an LCC analysis is chosen. First is the life span of the equipment. PV modules should operate for 20 years or more without failure. However, twenty years is the normal period chosen to evaluate PV projects [1]. Finally the $R_{\mathrm{PW}}$ subscript indicates the present worth of each factor The formula for the single present worth $\left(R_{\mathrm{PW}}\right)$ of a future sum of money $(F)$ in a given year $(N)$ at a given discount rate $(I)$ is

$$
R_{\mathrm{PW}}=\frac{F}{(1+I)^{N}} .
$$

After calculating the LCC, the unit cost of the energy produced by the system can be calculated as follows:

$$
\mathrm{CoE}=\frac{\mathrm{LCC}}{\sum_{1}^{n} E_{\mathrm{PV}}} .
$$

The payback period can be calculated as follows:

$$
\begin{aligned}
\mathrm{PBP} & =\frac{C_{\text {capital }}}{\text { Saving }_{\text {Annual }} * R_{\mathrm{PW}}} \\
& =\frac{C_{\text {capital }}(\mathrm{USD})}{E_{\mathrm{PV}_{\text {Annual }}}(\mathrm{kWh} / \text { year }) * \operatorname{CoE}(\mathrm{USD} / \mathrm{kWh}) * R_{\mathrm{PW}}} .
\end{aligned}
$$

\section{Results and Discussion}

In this paper a $100 \mathrm{kWp}$ grid PV system is assumed to be installed at each site. The modelled PV module specifications are shown in Table 2. As for the inverter, a $100 \mathrm{~kW}$ inverter is used. The conversion efficiency model of the used inverter can be described as follows:

$$
\begin{gathered}
\eta=-0.3253\left(\frac{P_{\mathrm{PV}}}{P_{\mathrm{INV}}}\right)^{-1.143}+97.49, \quad \frac{P_{\mathrm{PV}}}{P_{\mathrm{INV}_{R}}}>0, \\
\eta=0, \quad \frac{P_{\mathrm{PV}}}{P_{\mathrm{INV}_{R}}}=0 .
\end{gathered}
$$

Table 3 shows the assumed units cost for the PV system in calculating the LCC, CoE, and PBP. The life cycle time of the PV system is assumed to be 20 years.

5.1. Al-Wafra Site. Figure 5 shows the monthly mean daily energy generated (kWh/month) by the system. The annual energy generation by the system is $192.270 \mathrm{MWh}$. According to this the final yield factor for this system is $1922.7 \mathrm{kWh} /$ $\mathrm{kWp} /$ year. Meanwhile the average capacity factor is $22.25 \%$. As for the performance of the inverter, a performance factor for the inverter is defined in this paper. This performance factor equals to the ratio of the annual mean daily conversion efficiency to the rated efficiency provided by the manufacturer. Based on this the performance factor of the used inverter is $96.4 \%$. However, the LCC of the proposed system for Al-Wafra is 371000 USD. This means that the unit cost of this system is $0.0965 \mathrm{USD} / \mathrm{kWh}$ and the payback period is 15.6 years.
TABLE 2: PV modules specifications.

\begin{tabular}{lc}
\hline PV module type & KYOCERA (KC200GT) \\
PV module capacity & $200 \mathrm{Wp}$ \\
Maximum current & 7.10 \\
Maximum voltage & 16.9 \\
Open circuit voltage & 21.5 \\
Short circuit current & 7.45 \\
Efficiency $\left(G>200 \mathrm{~W} / \mathrm{m}^{2}\right)$ & $12.75 \%$ \\
Efficiency $\left(G<200 \mathrm{~W} / \mathrm{m}^{2}\right)$ & $14.5 \%$ \\
Temperature coefficient of power & $-3.9 \times 10^{-3} /{ }^{\circ} \mathrm{C}$ \\
\hline
\end{tabular}

TABLE 3: PV system units cost.

\begin{tabular}{lc}
\hline Unit & Price \\
\hline PV array & $3.8 / \mathrm{Wp} \mathrm{USD}$ \\
Inverter $100 \mathrm{kWp}$ & $32,000.00$ USD \\
O\&M & 500 USD/year \\
Salvage & $20 \%$ of the capital cost \\
Wires and circuit breakers & $7,000.00$ USD \\
Support structure & $5,000.00$ USD \\
Civil work and transportation & $3,000.00$ USD \\
Cost of kWh in Kuwait & 0.10 USD \\
\hline
\end{tabular}

5.2. Mutla Site. The mean monthly daily energy generated $(\mathrm{kWh} / \mathrm{month})$ by the system is shown in Figure 6. The annual energy generation by the system is $186.11 \mathrm{MWh}$. Meanwhile, the capacity factor for this system is $21.6 \%$ and the final yield factor is $1861 \mathrm{kWh} / \mathrm{kW}$ /year. The performance factor of the used inverter is $95.9 \%$. As for the system cost, the LCC of the proposed system for Al-Wafra is 371000 USD. In addition, the unit cost of this system is 0.0997 USD/kWh and the payback period is 16.1 years.

5.3. Systems Productivity Evaluation. As mentioned before, the yield factor and the capacity factor criteria are used to assist the productivity of the proposed systems. In general the capacity factor is used to assist the usage of a power source. The CF is ratio of the energy generated by these sources to the maximum energy that could be generated according to the source's ratings and for 24 hours. However, for a PV power source the sun is only available for 12 hours a day and thus the ideal CF is 0.5 due to the unavailability of sun during the night. In addition to that, the maximum real CF is slightly lower than 0.5 due to the energy conversion losses [8-10]. In general the typical CF for a PV array is in the range of 0.15-0.4 [8-10]. However, in this paper the maximum CF is 0.4557 after considering the assumed energy conversion losses. Figure 7 shows the monthly mean daily CF for both sites. The CF values for both systems are in the range of $(0.15-0.31)$ which means that both system's operation are in the typical operation zone.

On the other hand, the yield factor measures the productivity of the PV system. However, there is no typical range for the yield factor because this factor is a locationdependant factor. That is to say, each county (climate zone) 


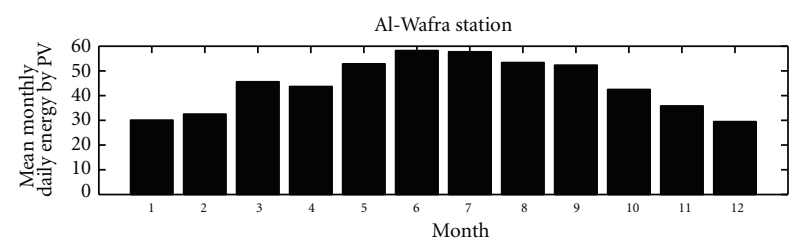

(a)

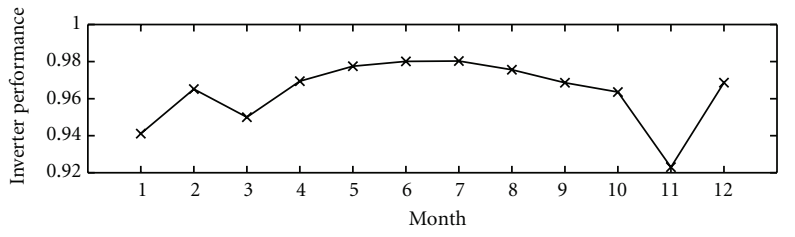

(b)

Figure 5: PV system performance at Al-Wafra site.

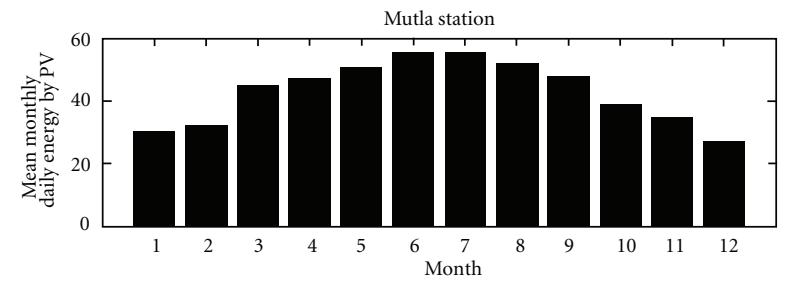

(a)

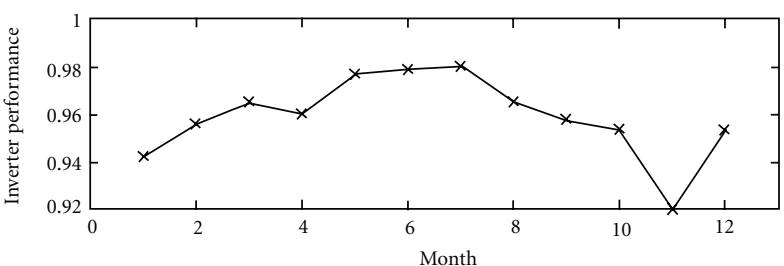

(b)

Figure 6: PV system performance at Mutla site.

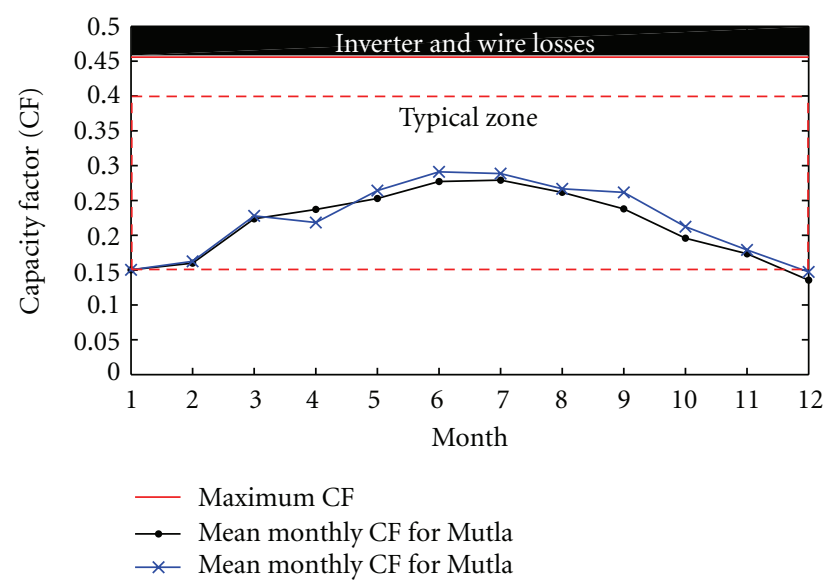

FIGURe 7: Monthly mean daily CF for Al-Wafra and Mutla sies.

has its own typical yield factor. In [10] the typical field factors for 6 countries are reported. The typical YF for Germany is in the range of $400-1300 \mathrm{kWh} / \mathrm{kWp} /$ year, while it is in the range of $470-1230 \mathrm{kWh} / \mathrm{kWp} /$ year for Japan. Furthermore, the typical yield factor for The Netherlands, Italy, Switzerland, and Israel are 400-900, 450-1250, 450-1400, and $740-2010 \mathrm{kWh} / \mathrm{kWp} /$ year, respectively. As for Kuwait, Figure 8 shows the range of the YF for both systems. The monthly mean of YF for Mutla is in the range of 97$201 \mathrm{kWh} / \mathrm{kWp} /$ month; meanwhile it is in the range of 106 209 for Al-Wafra. However, as mentioned before, the annual YF for Mutla and Al-Wafra are $1861 \mathrm{kWh} / \mathrm{kWp} /$ year and $1922.7 \mathrm{kWh} / \mathrm{kWp} /$ year, respectively. This proves that the PV technology in Kuwait has almost the best performance when compared to the counties reported by [10].

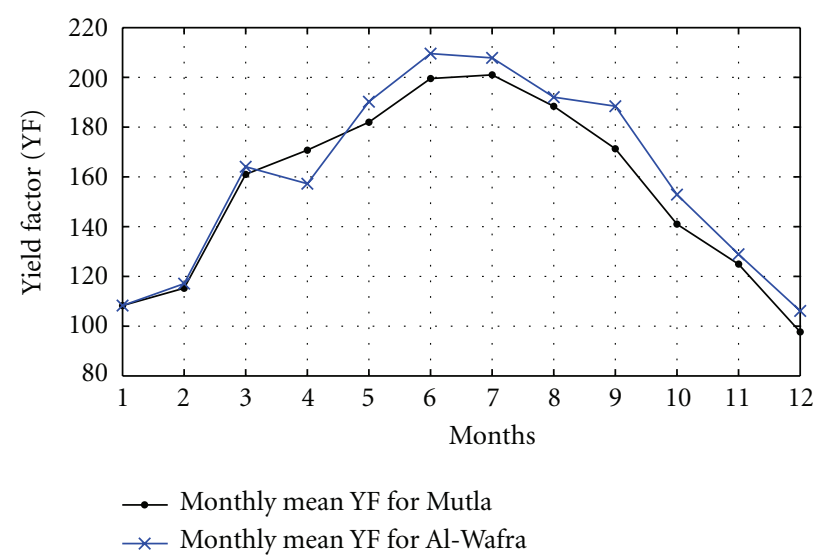

FIGURE 8: Monthly mean daily YF for Al-Wafra and Mutla sites.

\section{Conclusion}

In this paper the performance of a $100 \mathrm{kWp}$ grid-connected PV systems was studied for two sites, namely, Al-Wafra and Mutla in Kuwait. The proposed systems showed high energy productivity whereas the annual capacity factors for Mutla and Al-Wafra were $22.25 \%$ and $21.6 \%$, respectively. Meanwhile the annual yield factor for Mutla and Al-Wafra were $1861 \mathrm{kWh} / \mathrm{kWp} /$ year and $1922.7 \mathrm{kWh} / \mathrm{kWp} /$ year, respectively. On the other hand the cost of the energy generated by both systems was about 0.1 USD which is very close to the price of the cost of energy sold by the Kuwaiti electricity company. Furthermore the invested money is recovered during the assumed life cycle time whereas the payback period for both sites was about 15 years. Such a work is helpful for PV technology investments in Kuwait. 


\section{References}

[1] R. P. Mukund, Wind and Solar Energy, CRC Press, 1999.

[2] M. A. Eltawil and Z. Zhao, "Grid-connected photovoltaic power systems: technical and potential problems-a review," Renewable and Sustainable Energy Reviews, vol. 14, no. 1, pp. 112-129, 2010.

[3] T. Khatib, "A review of designing, installing and evaluating standalone photovoltaic power systems," Journal of Applied Sciences, vol. 10, no. 13, pp. 1212-1228, 2010.

[4] Ministry of Electricity \& Water (MEW), Electrical Energy. Edition 36A, Statistics Dept. \& Information Center, Ministry Of Electricity \& Water, 2011.

[5] The World Bank, “.” The World Bank Annual Report, 2010.

[6] A. H. Abdullah, A. A. Ghoneim, and A. Y. Al-Hasan, "Assesment of grid-connected photovoltaic systems in the Kuwaiti climate," Renewable Energy, vol. 26, no. 2, pp. 189-199, 2002.

[7] E. Kymakis, S. Kalykakis, and T. M. Papazoglou, "Performance analysis of a grid connected photovoltaic park on the island of crete," Energy Conversion and Management, vol. 50, no. 3, pp. 433-438, 2009.

[8] G. Privitera, A. R. Day, G. Dhesi, and D. Long, "Optimising the installation costs of renewable energy technologies in buildings: a linear programming approach," Energy and Buildings, vol. 43, no. 4, pp. 838-843, 2011.

[9] B. Rezaie, E. Esmailzadeh, and I. Dincer, "Renewable energy options for buildings: case studies," Energy and Buildings, vol. 43, no. 1, pp. 56-65, 2011.

[10] A. McEvoy, T. Markvart, and L. Castaner, Practical Handbook of Photovoltaics: Fundamentals and Applications, Elsevier, New York, NY, USA, 2011. 


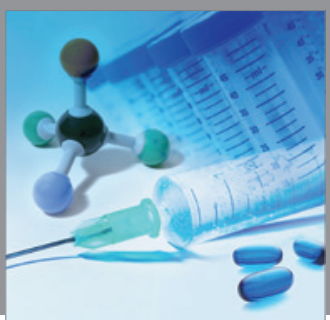

International Journal of

Medicinal Chemistry

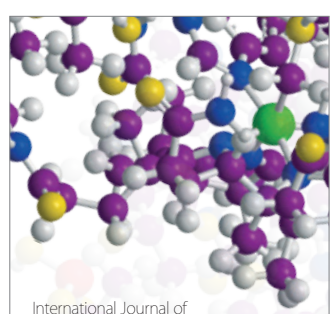

Carbohydrate Chemistry

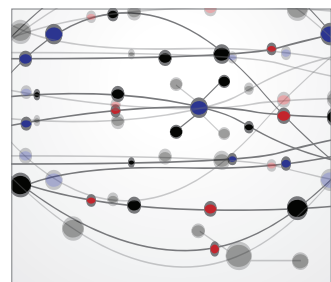

The Scientific World Journal
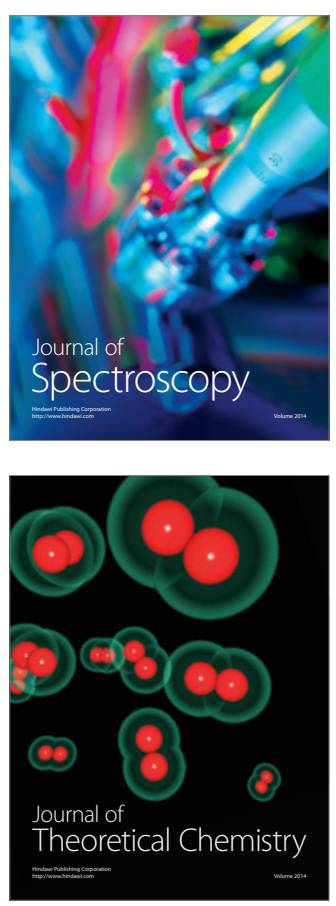
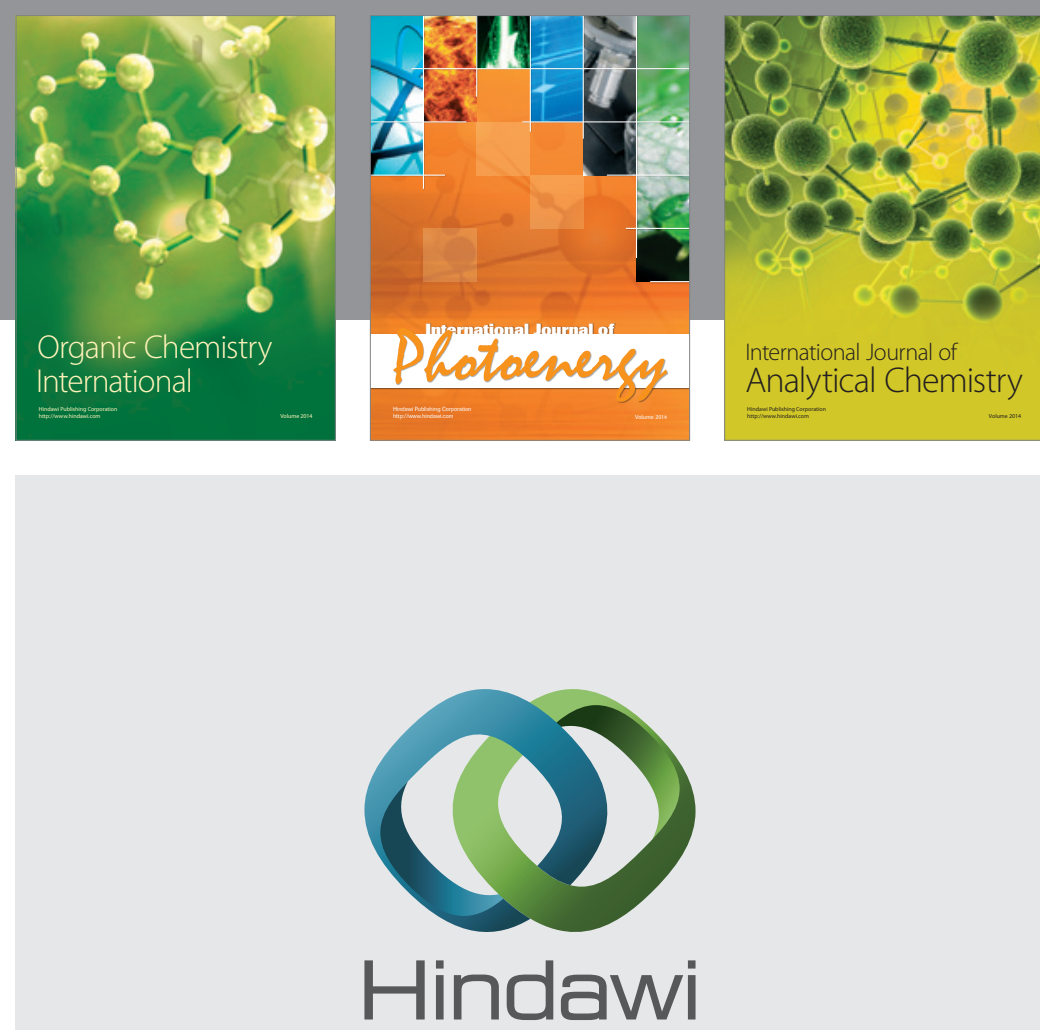

Submit your manuscripts at

http://www.hindawi.com
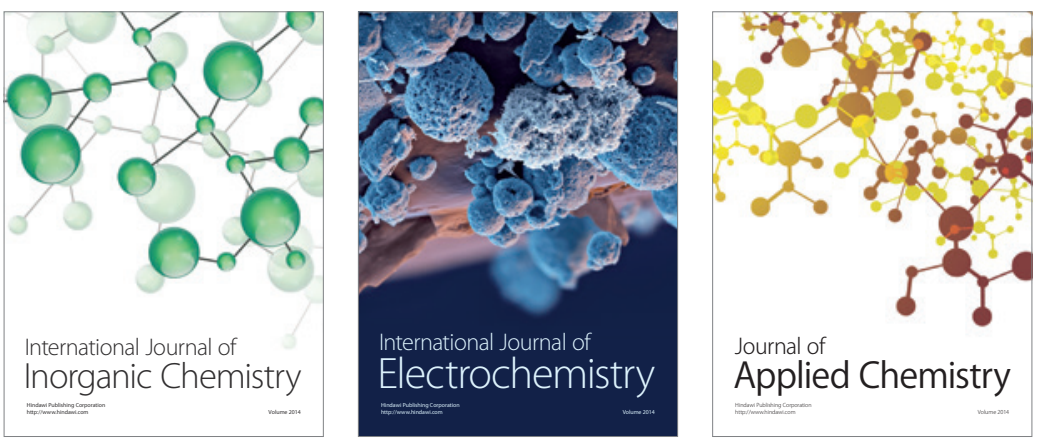

Journal of

Applied Chemistry
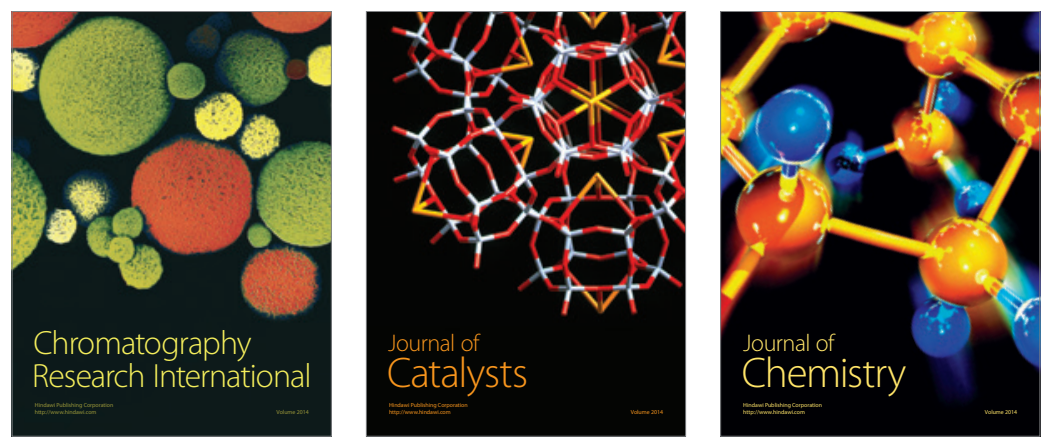
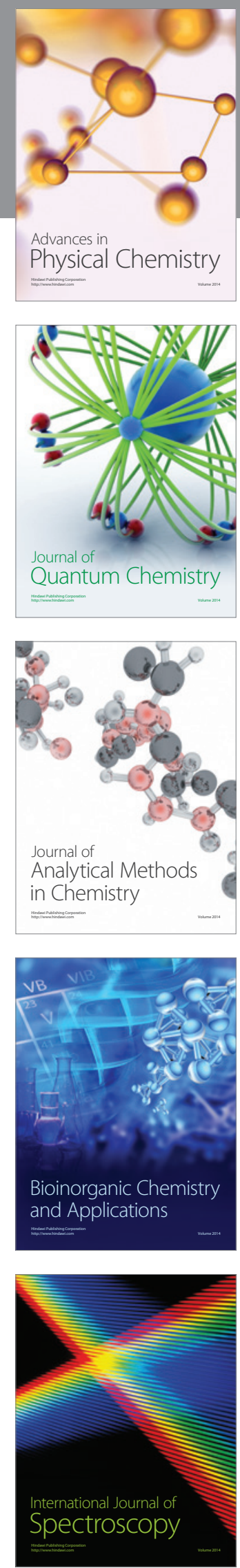